\title{
Comparative growth performance and carcass characteristics of guinea fowl (Numida meleagris) and three chicken genotypes
}

\author{
Getnet Zelleke ${ }^{1, *}$, Mengistu Urge ${ }^{2}$, Getachew Animut ${ }^{3}$, Wondmeneh Esatu ${ }^{4}$, Tadelle Dessie ${ }^{4}$ \\ ${ }^{1}$ Amhara Agricultural Research Institute, PO Box 527, Bahir Dar Ethiopia \\ ${ }^{2}$ Haramaya University, PO Box 138, Dire Dawa, Ethiopia \\ ${ }^{3}$ Agricultural Transformation Agency, PO Box 708, Addis Ababa, Ethiopia \\ ${ }^{4}$ International Livestock Research Institute, PO Box 5689, Addis Ababa, Ethiopia
}

\begin{abstract}
A study was conducted to compare the growth performance and carcass characteristics of guinea fowl (GF) with Horro (HR) and Tilili (TL) local chickens, and Potchefstroom Koekoek (PK) exotic chicken. Seventy-five-day-old chicks from each genotype were used in 3 replications in a completely randomized design. Commercial starter and grower feed was fed ad libitum during the 20 weeks of the study. Daily dry matter intake in $\mathrm{g} / \mathrm{bird}$ was greater for PK (70) than GF (63), HR (59), TL (61). The final body weight (FBW) g/bird was higher for PK (2022), intermediate for HR (1567) and TL (1539), and low for GF (1286). The average daily weight gain (ADG) was $9 \mathrm{~g} /$ bird for GF, $11 \mathrm{~g} /$ bird for HR and TL and $14 \mathrm{~g} / \mathrm{bird}$ for PK. The eviscerated weight $\mathrm{g}$ /bird was highest for PK (1679), followed by HR (1323) and TL (1249) and lowest for GF (913). The breast weight (g/bird) was higher for PK (436) than GF (281), HR (311), and TL (284). The thigh weight was higher for PK (303) and HR (252), followed by TL (208) and lowest for GF (157). The abdominal fat content was higher for PK (29 g), followed by HR and TL (12 g each), and low for GF $(6 \mathrm{~g})$. The ultimate $\mathrm{pH}_{24} \mathrm{~h}$ of the breast was higher for GF (6.0) followed by PK (5.8), HR and TL (5.7). GF had higher $\mathrm{pH}_{24 \mathrm{~h}}$ thigh meat (6.2), others had 5.8. The meat from GF was darker than normal in color compared to chickens. The GF, HR and TL local chickens could be used as alternate meat-type poultry species with continuous selection.
\end{abstract}

Keywords: Chicken; Growth; Guineafowl; Meat

DOI: https://dx.doi.org/10.4314/ejst.v15i1.6

\section{INTRODUCTION}

Poultry production has important economic, social and cultural benefits and plays a significant role in family nutrition and income generation in developing countries.

\footnotetext{
* Corresponding author: birukget2011@gmail.com

(C) This is an Open Access article distributed under the terms of the Creative Commons Attribution License (http://creativecommons.org/licenses/CC BY4.0)
} 
Under circumstances of extreme poverty where people cannot keep larger species of livestock due to shortage of land and capital, village chicken provide high-quality animal protein and income for the household (Copland and Alders, 2005). According to the World Population Review (2020), the human population of Ethiopia is estimated to be about 116 million with an annual growth rate of $2.6 \%$, which will significantly increase the demand for animal source food. Accordingly, the government has planned to double meat, egg and milk production to increase the current low production and to enhance livestock product consumption for food and nutrition security.

Poultry is considered to be the best option to lift the proposed plan of animal protein supply and to enhance livestock product consumption through increased egg and meat production within a short period of time. In this regard, besides importing high producing exotic chicken breeds, increasing productivity and use of alternate poultry species that are adapted to the local environment are indispensable. In line with this, guinea fowl can be an option to assist the smallholder and family poultry sector in the country and can contribute to the stretched demand for egg and meat as indicated in the Ethiopian Livestock Master Plan (Shapiro et al., 2015). Demand for guinea fowl meat is increasing throughout the world, and when compared with broilers, guinea fowl meat has higher protein and lower fat contents (CAB, 1987). Most consumers of poultry meat have certain expectations of flavor. However, most studies that focused on guinea-fowl meat quality were conducted in barn conditions (Tufarelli and Laudadio, 2015).

Although the smallholder farmers in Metema and Quara districts of the Amhara Regional State of Ethiopia started domesticating and keeping guinea fowl (Numida meleagris) for egg and meat production, for income generation and home consumption since the 1990s by introducing them from Sudan, the existence of these birds in Ethiopia was not assessed, tested and reported. Guinea fowls are reared traditionally under the extensive system just like the local chicken and hence their productivity is low. Domestic guinea fowls can be an important alternative poultry species with a promising future for both rural and commercial poultry production system not only due to increasing demand for its gamy flavored meat throughout the world but also for their great potential for providing the muchneeded animal protein in human diets in the developing countries (Premavalli, 2013).

Even though the available information about the growth performance and carcass traits of local chickens is minimal (Tadelle Dessie et al., 2003; Halima Moges, 2007; Nigussie Dana, 2011; Wondmeneh Esatu, 2015), there was no work done on domestic guinea fowls under indoor systems to investigate their growth performance, carcass yield and characteristics in Ethiopia. The comparative 
investigation of the performance of the guinea fowl with local and exotic chicken genotypes, and among the chicken genotypes will provide baseline information to design a genetic improvement strategy for these poultry species for future use as alternative meat-type birds in the country. Therefore, this study was carried out to compare growth performance, carcass yield and characteristics of these poultry types kept under indoor management systems.

\section{MATERIALS AND METHODS}

\section{Study area description}

The experiment was conducted at Andassa Livestock Research Center (ALRC) of Amhara Agricultural Research Institute (ARARI), Ethiopia. The centre is located at $11^{\circ} 29^{\prime} \mathrm{N}$ latitude and $37^{\circ} 29^{\prime} \mathrm{E}$ longitude with an elevation of 1730 meters above sea level. It receives an average annual rainfall of $1150 \mathrm{~mm}$ with a temperature ranging from 6.5 to $30^{\circ} \mathrm{C}$.

\section{Egg collection and hatching}

Eggs for Horro (HR) local chicken were obtained from the $11^{\text {th }}$ generation and Potchefstroom Koekoek (PK) from Debre Zeit Agricultural Research Center, whereas eggs for Tilili (TL) local chicken were collected from smallholder farmers in the Amhara Region, Awi administrative Zone, Tilili area, and domestic guinea fowl (GF) eggs were collected from households at Metema district, West Gondar Administrative Zone, Amhara Regional State of Ethiopia. The number of eggs acquired from the source area were 1100 for HR, 1200 for PK, 900 for TL, and 600 for GF. The eggs were transported to ALRC and stored for 24 hours at room temperature. The eggs were selected for artificial incubation based on size, shape, breakages, cleanliness, and fumigated with $37 \%$ formalin aqueous solution to disinfect the eggs against microbes. Seven $g$ of formalin solution per cubic meter of space were heated in an electric frying pan and held for 15 minutes in fumigating chamber with formaldehyde gas. Eggs were coded, tagged and incubated in Pas Reform setter (Smart Set ${ }^{\mathrm{TM}}$ of Pas Reform Hatchery Technology BV, The Netherlands) on a separate tray. Eggs were candled on the $9^{\text {th }}$ day of incubation for fertile and clear eggs and transferred at the $19^{\text {th }}$ day of incubation to Smart Hatch ${ }^{\mathrm{TM}}$ hatchery on a separate hatch basket, which was coded with the respective genotypes. Guinea fowl eggs were incubated 7 days ahead of chicken eggs since the hatching date for guinea fowl eggs takes 28 days. Hatched chicks and keets (baby guinea fowl) were used for the study by keeping them under an intensive management system. 


\section{Management of experimental animals}

A total of 75 unsexed baby chicks from each of the poultry genotypes were randomly taken from each of the hatch baskets. Study treatments were the four poultry genotypes in a completely randomized design (CRD). Each treatment was replicated three times comprising of 25 birds per replicate. Pens with a size of $3.5 \mathrm{~m}$ $\times 3.5 \mathrm{~m}$ were prepared for guinea fowls and covered with $0.5 \times 0.5 \mathrm{~cm}$ wire mesh to prevent birds from flying out. Nine pens $(2.5 \mathrm{~m} \times 2.5 \mathrm{~m})$ were made and used for the chicken genotypes. The pens, watering and feeding troughs were thoroughly cleaned, disinfected and sprayed with hydrogen peroxide against external parasites before the commencement of the experiment. The floor of each pen was bedded with disinfected grass hay and was replaced when deemed appropriate. The birds were brooded by using 1500-Watt Infra-red electric heaters with gradual hanging height adjustments as a source of heat. The white light bulbs were used for lighting in the experimental house. All chicks and keets were vaccinated against Newcastle, Gumburo (Infectious Bursal Disease-IBD) and Fowl Typhoid diseases using appropriate vaccine according to the manufacturer's recommendation. Birds were fed commercial starter ration up to week 8 and grower ration from week 9 to week 20 (Table 1).

Table 1. Nutrient composition of the diet fed to experimental birds.

\begin{tabular}{lcc}
\hline Nutrients & Starter & Grower \\
\hline Metabolizable energy (ME-Kcal $/ \mathrm{kg})$ & 3000.0 & 2950.0 \\
Crude protein (\% DM) & 20.5 & 18.8 \\
Crude fiber (\% DM) & 5.5 & 5.8 \\
Calcium (\% DM) & 0.9 & 0.9 \\
Fat (\% DM) & 6.5 & 5.0 \\
Moisture (\%) & 10.0 & 10.0 \\
\hline
\end{tabular}

The composition is as provided by the manufacturer (Alema Koudjis Feed PLC, Debre Zeit, Ethiopia); DM = Dry matter.

\section{Dry matter intake, average daily gain and feed conversion ratio}

Commercial starter and grower feed was offered ad libitum twice per day at 0800 and 1700 hours and clean tap water were available all the time. The amount of feed offered and refused per pen was recorded daily, and the amount consumed was determined as the difference between the amount offered and refused. Before the allocation of the birds to the experimental pens, initial body weight (IBW) was taken individually and the average weight was calculated by using an electronic sensitive balance of $0.01 \mathrm{~g}$ precision. Then, birds were individually weighed at weekly intervals for the entire experimental period and the pen average of both 
sexes was calculated. Bodyweight change (BWC) was calculated as the difference between the final body weight (FBW) and IBW. Average daily gain (ADG) was calculated as BWC divided by the number of experimental days. The feed conversion ratio (FCR) was computed as the ratio of daily dry matter (DM) intake per average daily gain. Mortality was registered as it occurred and general health status was monitored throughout the experiment.

\section{Carcass measurements}

At the end of the experiment, three randomly selected male birds from each replicate were withdrawn from feed for 12 hours, weighed and exsanguinated by severing the neck. The body was dry de-feathered by hand plucking and eviscerated and carcass cuts and non-edible offal components were determined according to the procedure described before (Kubena et al., 1974; Kekeocha, 1985). Dressed carcass weight was measured after the removal of blood and feather and the dressing percentage was calculated as the proportion of dressed carcass weight to slaughter weight multiplied by 100 . The shank, head, kidney, lungs, pancreas, crop, proventriculus, small intestine, large intestine, caeca and urogenital tracts were removed from the dressed carcass and eviscerated percentage was computed as the proportion of the eviscerated weight to slaughter weight. From eviscerated carcass, drumstick, thigh and breast meat were separated, weighed and expressed as a percentage of slaughter weight. Fat around the proventriculus, gizzard and against the abdominal wall and the cloacae were removed and weighed, and the abdominal fat percentage was calculated as a percentage of slaughter weight. The edible offal components (heart, gizzard and liver) were expressed as a percentage of slaughter weight. Weight of the gastrointestinal tract parts was weighed without contents and slaughter body weight. The lengths of the gut parts were measured using a measuring tape.

\section{Meat $\mathrm{pH}$ and color measurements}

Meat $\mathrm{pH}$ was measured at fifteen minutes $\left(\mathrm{pH}_{15 \min }\right)$ and twenty-four hours $\left(\mathrm{pH}_{24 \mathrm{~h}}\right)$ of postmortem after evisceration using a penetrating glass electrode of a portable meat $\mathrm{pH}$ meter (HI99163, HANAN) on the breast and thigh muscle. The probe was calibrated with $\mathrm{pH} 4.1$ and 7.1 standard buffer solutions. The electrode pointer was thoroughly cleaned with distilled water and a cotton towel before and after each reading. For meat color measurements, the cut surface of samples frozen at $4{ }^{\circ} \mathrm{C}$ was freshly exposed on a flat surface of the white background and allowed to bloom for about 30 minutes at ambient temperature. Then, meat color parameters, i.e., CIE $\mathrm{L}^{*} \mathrm{a} \mathrm{b}^{*}$ values $\left(\mathrm{L}^{*}=\right.$ lightness, $\mathrm{a}^{*}=$ redness and $\mathrm{b}^{*}=$ yellowness $)$ were obtained using the digital colorimeter (Hunter Lab MiniScanEZ, Serial No. Ms EZ1547, 
$45 / 0^{\circ}$ illumination/viewing system, D65 light source, and $10^{\circ}$ observer angle) calibrated with black and white standardized calibration plates between sample measurements (AMSA, 2012). Three random readings at different locations per sample were taken and averaged.

\section{Statistical analysis}

Data were analyzed using the general linear model procedure of Statistical Analysis Systems Software (SAS, 2009). When F-test declare significant differences at $\alpha<$ 0.05 , differences among treatment means were separated using Tukey Kuramer Test. The model used for data analysis was $Y_{i j}=\mu+G_{i}+e_{i j}$. Where: $Y_{i j}=$ represents the $\mathrm{j}$ observation in the $\mathrm{i}^{\text {th }}$ breed level; $\mu=$ overall mean; $\mathrm{G}_{\mathrm{i}}=$ genotype effect; and $\mathrm{e}_{\mathrm{ij}}=$ random error.

\section{RESULTS}

\section{Dry matter intake, average daily gain and feed conversion ratio}

Dry matter intake during the starter and finisher phase as well as the entire experimental period was higher $(p<0.05)$ for PK than HR and TL (Table 2). Dry matter intake of GF was similar to that of PK during the starter phase but consumed less feed in the finisher and the whole experiment compared to PK, and GF has greater feed intake than HR and TL for the entire experiment $(p<0.05)$. The hatched-out weight (IBW) was significantly highest $(p<0.0001)$ for PK, followed by HR and TL and lowest for GF. The FBW during the starter phase for PK was significantly higher, intermediate for GF, lowest for HR and TL $(p<0.0001)$. The starter phase BWC and ADG for PK and GF were significantly higher $(p<0.0001)$ than that for HR and TL local chickens. Although no FCR difference was observed among GF, HR, and TL, the values were significantly higher $(p<0.0001)$ than the FCR values. However, PK has relatively a better ratio value during the starter phase than the grower and the entire experiment period. The BWC and ADG during the growing phase were significantly highest for PK, intermediate for HR and TL and lowest for GF $(p<0.0001)$. The final $\mathrm{BW}, \mathrm{BWC}$ and ADG during the entire experiment period were significantly highest $(p<0.0001)$ for PK, intermediate for HR and TL and the lowest for GF. There were no differences $(p>0.05)$ in the survival rate among the genotypes and the mortality was within the acceptable rate.

\section{Carcass measurements}

Carcass weights of slaughter, dressing, wing, back, and eviscerated were significantly higher for PK $(p<0.0001)$ than other genotypes (Table 3$)$. Dressing, 
eviscerated, thigh, wing, and neck percentages were not $(p>0.05)$ different among genotypes. Breast weight was significantly higher $(p<0.0001)$ for PK, but similar among GF, HR, and TL genotypes. The proportion of breast was significantly highest $(p<0.05)$ for GF, intermediate for HR and PK, and lowest for TL.

Table 2. Performances of different poultry genotypes kept under an intensive management system.

\begin{tabular}{|c|c|c|c|c|c|c|}
\hline \multirow[t]{2}{*}{ Parameters } & \multicolumn{4}{|c|}{ Genotypes } & \multirow[t]{2}{*}{ SE } & \multirow[t]{2}{*}{$p$-value } \\
\hline & GF & HR & TL & PK & & \\
\hline \multicolumn{7}{|c|}{ Starter phase (0-8 weeks) } \\
\hline IBW (g/bird) & $21.7^{\mathrm{c}}$ & $31.5^{b}$ & $31.8^{\mathrm{b}}$ & $35.6^{\mathrm{a}}$ & 0.36 & $<0.0001$ \\
\hline DM intake (g/bird) & $48.9^{\mathrm{ab}}$ & $48.1^{\mathrm{b}}$ & $47.7^{b}$ & $50.0^{\mathrm{a}}$ & 0.49 & 0.0480 \\
\hline FBW (g/bird) & $696.9^{b}$ & $635.5^{\mathrm{c}}$ & $644.2^{\mathrm{c}}$ & $740.7^{\mathrm{a}}$ & 11.96 & $<0.0001$ \\
\hline (g/bird) & $675.3^{\mathrm{a}}$ & $603.9^{b}$ & $612.4^{\mathrm{b}}$ & $705.1^{\mathrm{a}}$ & 12.15 & $<0.0001$ \\
\hline $\mathrm{ADG}$ & $12.1^{\mathrm{a}}$ & $10.8^{\mathrm{b}}$ & $10.9^{\mathrm{b}}$ & $12.6^{\mathrm{a}}$ & 0.21 & $<0.0001$ \\
\hline FCR ( & $4.1^{\mathrm{a}}$ & $4.5^{\mathrm{a}}$ & $4.4^{\mathrm{a}}$ & $3.9^{\mathrm{b}}$ & 0.05 & $<0.0001$ \\
\hline Surviy & 96.0 & 96.0 & 94.7 & 97.3 & 0.94 & 0.3300 \\
\hline \multicolumn{7}{|c|}{ Growing phase (8-20 weeks) } \\
\hline DM intake $(\mathrm{g} / \mathrm{bir}$ & $76.4^{\mathrm{b}}$ & $70.2^{c}$ & $73.6 b^{c}$ & $90.5^{\mathrm{a}}$ & 1.17 & $<0.0001$ \\
\hline BWC (g/bird) & $589.2^{\mathrm{c}}$ & $931.7^{\mathrm{b}}$ & $894.3^{\mathrm{b}}$ & $1280.9^{\mathrm{a}}$ & 20.38 & $<0.0001$ \\
\hline ADG (g/day) & $6.5^{\mathrm{c}}$ & $10.2^{\mathrm{b}}$ & $9.8^{\mathrm{b}}$ & $14.1^{\mathrm{a}}$ & 0.22 & $<0.0001$ \\
\hline FCR & $11.8^{\mathrm{a}}$ & $6.9 b^{c}$ & $7.5^{\mathrm{b}}$ & $6.4^{\mathrm{c}}$ & 0.23 & $<0.0001$ \\
\hline Survival (\%) & 97.2 & 94.4 & 95.8 & 97.2 & 1.20 & 0.3630 \\
\hline \multicolumn{7}{|c|}{ Entire experiment (0-20 weeks) } \\
\hline DM intake (g/bird) & $62.7^{b}$ & $59.1^{\mathrm{c}}$ & 60.7 & $70.3^{\mathrm{a}}$ & 0.61 & $<0.0001$ \\
\hline FBW (g/bird) & $1286.2^{c}$ & $1567.1^{\mathrm{b}}$ & $1538.5^{b}$ & $2021.6^{\mathrm{a}}$ & 14.00 & $<0.0001$ \\
\hline BWC (g/bird) & $1264.5^{c}$ & $1535.6^{\mathrm{b}}$ & $1506.7^{\mathrm{b}}$ & $1985.9^{\mathrm{a}}$ & 13.99 & $<0.0001$ \\
\hline ADG (g/day) & $9.0^{\mathrm{c}}$ & $11.0^{\mathrm{b}}$ & $10.8^{\mathrm{b}}$ & $14.2^{\mathrm{a}}$ & 0.69 & $<0.0001$ \\
\hline FCR & $6.9^{\mathrm{a}}$ & $5.4^{\mathrm{c}}$ & $5.6^{\mathrm{b}}$ & $6.0^{\mathrm{a}}$ & 0.07 & $<0.0001$ \\
\hline Survival (\%) & 93.3 & 90.7 & 90.7 & 94.7 & 1.76 & 0.3430 \\
\hline
\end{tabular}

a,b,c Means within a row with different superscripts differ $(p<0.05)$; GF = Guineafowl; $\mathrm{HR}=$ Horro local chicken; $\mathrm{TL}=$ Tilili local chicken; $\mathrm{PK}=$ Potchefstroom Koekoek; $\mathrm{SE}=$ Standard error of the mean; DM = Dry matter; IBW = initial bodyweight; FBW = final bodyweight; $\mathrm{BWC}=$ bodyweight change; $\mathrm{ADG}=$ Average daily weight gain $; \mathrm{FCR}=$ Feed Conversion Ratio.

The thigh and drumstick cut weights were significantly higher $(p<0.0001)$ for the PK and HR and intermediate for TL and lowest for GF genotypes. The proportion of thigh was similar $(p>0.05)$ across all genotypes, whereas the proportion of drumstick was significantly highest for HR and TL, followed by PK and lowest for GF $(p<0.0001)$. The highest $(p<0.01)$ neck weight was measured for PK and TL, 
intermediate for HR and lowest for GF. Compared to guinea fowls, chickens recorded higher weights for the heart, liver, and gizzard. Among the chicken genotypes, PK recorded significantly greater weights of the edible offal components $(p<0.0001)$. However, the percentage share of the edible offal components was not different $(\mathrm{p}>0.05)$ among all genotypes.

Table 3. Carcass components of meat from different poultry genotypes kept under an intensive system.

\begin{tabular}{|c|c|c|c|c|c|c|}
\hline \multirow[t]{2}{*}{ Parameters } & \multicolumn{4}{|c|}{ Genotypes } & \multirow[t]{2}{*}{ SE } & \multirow[t]{2}{*}{$p$-value } \\
\hline & GF & HR & TL & PK & & \\
\hline Slaughter weight (g) & $1308.3^{\mathrm{c}}$ & $1853.9^{\mathrm{b}}$ & $1788.9^{\mathrm{b}}$ & $2448.4^{\mathrm{a}}$ & 86.58 & $<0.0001$ \\
\hline Dressed weight (g) & $966.7^{\mathrm{c}}$ & $1388.1^{\mathrm{b}}$ & $1310.4^{\mathrm{b}}$ & $1759.1^{\mathrm{a}}$ & 58.61 & $<0.0001$ \\
\hline Dressing (\%) & 73.8 & 74.8 & 73.2 & 72.2 & 1.19 & 0.4740 \\
\hline $\begin{array}{l}\text { Eviscerated weight } \\
(\mathrm{g})\end{array}$ & $913.1^{\mathrm{c}}$ & $1322.8^{\mathrm{b}}$ & $1249.1^{\mathrm{b}}$ & $1679.3^{\mathrm{a}}$ & 57.12 & $<0.0001$ \\
\hline Eviscerated (\%) & 69.7 & 71.3 & 69.7 & 68.9 & 1.14 & 0.5080 \\
\hline Breast weight (g) & $281.3^{\mathrm{b}}$ & $310.7^{b}$ & $283.8^{\mathrm{b}}$ & $436.3^{\mathrm{a}}$ & 16.77 & $<0.0001$ \\
\hline Breast $(\%)$ & $21.4^{\mathrm{a}}$ & $16.7^{\mathrm{b}}$ & $15.8^{\mathrm{c}}$ & $17.9^{\mathrm{b}}$ & 0.59 & $<0.0001$ \\
\hline Thigh weight (g) & $157.3^{\mathrm{c}}$ & $252.2^{\mathrm{ab}}$ & $208.0^{\mathrm{b}}$ & $303.0^{\mathrm{a}}$ & 17.02 & $<0.0001$ \\
\hline Thigh (\%) & 12.0 & 13.6 & 11.6 & 12.0 & 0.58 & 0.1292 \\
\hline $\begin{array}{l}\text { Drumstick weight } \\
\text { (g) }\end{array}$ & $113.8^{\mathrm{c}}$ & $231.3^{\mathrm{ab}}$ & $209.6^{\mathrm{b}}$ & $262.9^{a}$ & 12.84 & $<0.0001$ \\
\hline Drum stick (\%) & $8.7^{\mathrm{c}}$ & $12.5^{\mathrm{a}}$ & $11.7^{\mathrm{ab}}$ & $10.8^{\mathrm{b}}$ & 0.43 & $<0.0001$ \\
\hline Wing weight (g) & $64.9^{c}$ & $83.7^{\mathrm{b}}$ & $83.9^{\mathrm{b}}$ & $104.3^{\mathrm{a}}$ & 4.95 & 0.0002 \\
\hline Wing (\%) & 5.0 & 4.5 & 4.7 & 4.3 & 0.23 & 0.2243 \\
\hline Back weight (g) & $110.2^{c}$ & $157.6^{\mathrm{b}}$ & $170.1^{\mathrm{b}}$ & $236.8^{\mathrm{a}}$ & 12.95 & $<0.0001$ \\
\hline Neck weight (g) & $48.4^{\mathrm{c}}$ & $63.9^{\mathrm{b}}$ & $70.0^{\mathrm{ab}}$ & $94.5^{\mathrm{a}}$ & 5.23 & 0.0018 \\
\hline Neck (\%) & 3.7 & 3.4 & 3.9 & 3.8 & 0.20 & 0.4970 \\
\hline Gizzard weight (g) & $22.4^{\mathrm{c}}$ & $26.7^{\mathrm{b}}$ & $27.4^{\mathrm{b}}$ & $42.4^{\mathrm{a}}$ & 1.43 & $<0.0001$ \\
\hline Gizzard (\%) & 1.7 & 1.4 & 1.5 & 1.8 & 0.10 & 0.1415 \\
\hline Liver weight (g) & $17.1^{\mathrm{c}}$ & $25.1^{\mathrm{b}}$ & $27.3^{\mathrm{b}}$ & $35.7^{\mathrm{a}}$ & 1.96 & $<0.0001$ \\
\hline Liver (\%) & 1.3 & 1.4 & 1.5 & 1.5 & 0.12 & 0.5061 \\
\hline Heart $(\mathrm{g})$ & $6.7^{\mathrm{c}}$ & $9.7^{\mathrm{b}}$ & $9.4^{\mathrm{b}}$ & $11.2^{\mathrm{a}}$ & 0.54 & $<0.0001$ \\
\hline Heart (\%) & 0.5 & 0.5 & 0.5 & 0.4 & 0.03 & 0.4940 \\
\hline Abdominal fat (g) & $6.1^{\mathrm{c}}$ & $12.1^{\mathrm{b}}$ & $11.2^{\mathrm{b}}$ & $29.3^{\mathrm{a}}$ & 1.61 & $<0.0001$ \\
\hline Abdominal fat (\%) & $0.5^{\mathrm{b}}$ & $0.7^{\mathrm{b}}$ & $0.6^{\mathrm{b}}$ & $1.2^{\mathrm{a}}$ & 0.07 & $<0.0001$ \\
\hline
\end{tabular}

The abdominal fat weight was significantly highest $(p<0.05)$ for PK, intermediate for local chicken genotypes and lowest for GF. The percentage of the abdominal fat was significantly higher for PK than the other chicken genotypes. The meat from GF was leaner compared to chicken genotypes. 
Chicken genotypes had significantly heavier and longer $(p<0.0001)$ small and large intestines than guinea fowls (Table 4). However, among the chicken genotypes, PK had the heaviest and longest small and large intestines. The esophagus and crop weight were significantly higher $(p<0.0001)$ for PK, followed by HR and lowest for GF and TL. The proventriculus weight was the highest for PK, intermediate for TL and lowest for GF and HR. Guinea fowl had significantly higher weight and longer caeca than other genotypes. The length of the proventriculus was the highest for PK and TL, and GF was intermediate whereas, HR has the shortest $(p<0.01)$.

Table 4. Weight and length of gut parts of male birds from different poultry genotypes kept under an intensive system.

\begin{tabular}{|c|c|c|c|c|c|c|}
\hline \multirow[t]{2}{*}{ Parameters } & \multicolumn{4}{|c|}{ Genotypes } & \multirow[t]{2}{*}{ SE } & \multirow[t]{2}{*}{$p$-value } \\
\hline & GF & HR & TL & PK & & \\
\hline Esophagus and crop weight (g) & $8.9^{c}$ & $9.7^{\mathrm{b}}$ & $8.5^{\mathrm{c}}$ & $12.0^{\mathrm{a}}$ & 0.19 & $<0.0001$ \\
\hline Proventriculus weight $(\mathrm{g})$ & $6.6^{\mathrm{c}}$ & $6.8^{\mathrm{c}}$ & $8.1^{\mathrm{b}}$ & $9.5^{\mathrm{a}}$ & 0.28 & $<0.0001$ \\
\hline Small intestine weight (g) & $46.2^{\mathrm{c}}$ & $62.5^{\mathrm{b}}$ & $64.7^{\mathrm{b}}$ & $84.9^{\mathrm{a}}$ & 2.05 & $<0.0001$ \\
\hline Large intestine weight (g) & $5.6^{\mathrm{c}}$ & $7.2^{\mathrm{b}}$ & $7.1^{\mathrm{b}}$ & $8.2^{\mathrm{a}}$ & 0.24 & $<0.0001$ \\
\hline Caeca weight $(\mathrm{g})$ & $8.9^{\mathrm{a}}$ & $7.2^{\mathrm{b}}$ & $7.1^{\mathrm{b}}$ & $7.6^{\mathrm{b}}$ & 0.27 & 0.0004 \\
\hline $\begin{array}{l}\text { Esophagus and crop length } \\
\text { (cm) }\end{array}$ & 13.6 & 14.2 & 12.7 & 15.2 & 0.86 & 0.2505 \\
\hline Proventriculus length $(\mathrm{cm})$ & $5.0 b^{\mathrm{c}}$ & $4.1^{\mathrm{c}}$ & $5.8^{\mathrm{ab}}$ & $7.2^{\mathrm{a}}$ & 0.49 & 0.0023 \\
\hline Small intestine length $(\mathrm{cm})$ & $86.4^{\mathrm{c}}$ & $108.3^{\mathrm{b}}$ & $111.3^{\mathrm{b}}$ & $138.8^{\mathrm{a}}$ & 3.19 & $<0.0001$ \\
\hline Large intestine length $(\mathrm{cm})$ & $21.1^{\mathrm{c}}$ & $26.0^{\mathrm{b}}$ & $25.0^{\mathrm{b}}$ & $33.5^{\mathrm{a}}$ & 1.06 & $<0.0001$ \\
\hline Caeca length $(\mathrm{cm})$ & $16.5^{\mathrm{a}}$ & $13.1^{\mathrm{c}}$ & $13.4^{\mathrm{c}}$ & $14.4^{\mathrm{b}}$ & 0.31 & $<0.0001$ \\
\hline
\end{tabular}

a,b,c Means within a row with different superscripts differ $(\mathrm{P}<0.05)$; $\mathrm{GF}=$ Guineafowl; $\mathrm{HR}=$ Horro local chicken; $\mathrm{TL}=$ Tilili local chicken; $\mathrm{PK}=$ Potchefstroom Koekoek; $\mathrm{SE}=$ Standard error of the mean.

\section{Meat pH and color measurements}

The breast muscle $\mathrm{pH}_{15 \min }, \mathrm{pH}_{24 \mathrm{~h}}$ and the thigh meat $\mathrm{pH}_{15 \mathrm{~min}}$ were significantly highest for GF, followed by PK, and lowest for HR and TL. Thigh muscle $\mathrm{pH}_{24 \mathrm{~h}}$ was significantly higher $(p<0.0001)$ in GF than the rest of chicken genotypes, while there was no difference among the chicken genotypes (Table 5). However, the ultimate $\mathrm{pH}\left(\mathrm{pH}_{24 \mathrm{~h}}\right)$ values for both meat cuts tended to be lower compared to the initial $\left(\mathrm{pH}_{15 \mathrm{~min}}\right)$ values. The breast meat color after 15 minutes and $24 \mathrm{~h}$ of postmortem was not different $(p>0.05)$ among all of the genotypes although breast meat in GF tended to be redder $(p<0.09)$. The lightness $\left(\mathrm{L}^{*}\right)$ color of the thigh meat of chicken genotypes was significantly higher $(p<0.01)$ compared to GF both at initial and 24 hours readings. The redness $\left(\mathrm{a}^{*}\right)$ color for breast and thigh meat from GF after $24 \mathrm{~h}$ of storage were significantly higher $(p<0.0001)$ than the rest of 
chicken genotypes, whereas chickens showed similar redness $\left(\mathrm{a}^{*}\right)$ reading. There was no difference $(p>0.05)$ in yellowness $\left(b^{*}\right)$ color of breast meat across all of the genotypes after cold storage. However, the yellowness $\left(\mathrm{b}^{*}\right)$ values of thigh muscle cut after storage for $24 \mathrm{~h}$ showed the highest $(p<0.0001)$ for HR and PK but intermediate for TL and lowest for GF genotypes.

Table 5. Initial and ultimate $\mathrm{pH}$ and color of breast and thigh meat from different poultry genotypes kept under an intensive system.

\begin{tabular}{llrrrrrr}
\hline & Parameters & GF & HR & TL & PK & SE & $\begin{array}{c}\boldsymbol{p} \text { - } \\
\text { value }\end{array}$ \\
\hline Breast & $\mathrm{pH}_{15 \min }$ & $6.2^{\mathrm{a}}$ & $5.8^{\mathrm{c}}$ & $5.8^{\mathrm{c}}$ & $6.0^{\mathrm{b}}$ & 0.03 & 0.000 \\
(Pectoralis & $\mathrm{L}^{*}$ & 47.2 & 51.0 & 50.5 & 51.0 & 2.08 & 0.463 \\
major) & $\mathrm{a}^{*}$ & 5.3 & 4.0 & 3.3 & 4.1 & 0.52 & 0.090 \\
& $\mathrm{~b}^{*}$ & 12.2 & 12.3 & 12.0 & 12.7 & 0.58 & 0.868 \\
& $\mathrm{pH}_{24 \mathrm{~h}}$ & $6.0^{\mathrm{a}}$ & $5.7^{\mathrm{c}}$ & $5.7^{\mathrm{c}}$ & $5.8^{\mathrm{b}}$ & 0.02 & 0.000 \\
& $\mathrm{~L}^{*}$ & 45.5 & 51.0 & 51.8 & 49.8 & 2.59 & 0.352 \\
& $\mathrm{a}^{*}$ & $8.6^{\mathrm{a}}$ & $6.1^{\mathrm{b}}$ & $5.9^{\mathrm{b}}$ & $5.2^{\mathrm{b}}$ & 0.46 & 0.000 \\
& $\mathrm{~b}^{*}$ & 11.9 & 11.9 & 10.5 & 11.8 & 0.89 & 0.635 \\
& & & & & & & \\
Thigh & $\mathrm{pH}_{15 \min }$ & $6.4^{\mathrm{a}}$ & $5.9^{\mathrm{c}}$ & $5.9^{\mathrm{c}}$ & $6.1^{\mathrm{b}}$ & 0.03 & 0.000 \\
(biceps & $\mathrm{L}^{*}$ & $36.5^{\mathrm{b}}$ & $43.9^{\mathrm{a}}$ & $43.9^{\mathrm{a}}$ & $44.2^{\mathrm{a}}$ & 1.49 & 0.003 \\
femoris) & $\mathrm{a}^{*}$ & $10.3^{\mathrm{a}}$ & $8.3^{\mathrm{b}}$ & $7.3^{\mathrm{b}}$ & $7.4^{\mathrm{b}}$ & 0.62 & 0.011 \\
& $\mathrm{~b}^{*}$ & 10.8 & 14.1 & 11.9 & 10.9 & 1.35 & 0.304 \\
& $\mathrm{pH}_{24 \mathrm{~h}}$ & $6.2^{\mathrm{a}}$ & $5.8^{\mathrm{b}}$ & $5.8^{\mathrm{b}}$ & $5.8^{\mathrm{b}}$ & 0.05 & 0.000 \\
& $\mathrm{~L}^{*}$ & $35.2^{\mathrm{b}}$ & $45.9^{\mathrm{a}}$ & $44.4^{\mathrm{a}}$ & $44.9^{\mathrm{a}}$ & 1.25 & 0.000 \\
& $\mathrm{a}^{*}$ & $10.5^{\mathrm{a}}$ & $8.9^{\mathrm{b}}$ & $7.6^{\mathrm{b}}$ & $8.1^{\mathrm{b}}$ & 0.42 & 0.000 \\
& $\mathrm{~b}^{*}$ & $7.7^{\mathrm{c}}$ & $10.8^{\mathrm{ab}}$ & $9.5^{\mathrm{b}}$ & $11.4^{\mathrm{a}}$ & 0.48 & 0.000 \\
\hline
\end{tabular}

a,b,c Means within a row with different superscripts differ $(\mathrm{P}<0.05) ; \mathrm{pH}_{15}=\mathrm{pH}$ value after 15 minutes of postmortem; $\mathrm{pH}_{24}=$ meat $\mathrm{pH}$ value after 24 hours; $\mathrm{L}^{*}=$ lightness; $\mathrm{a}^{*}=$ redness; $\mathrm{b}^{*}=$ yellowness; $\mathrm{GF}=$ Guineafowl; HR= Horro local chicken; $\mathrm{TL}=$ Tilili local chicken; $\mathrm{PK}=$ Potchefstroom Koekoek; SEM $=$ Standard error of the mean.

\section{DISCUSSION}

The ADG of GF during starter phase was higher and similar with PK as compared to other chicken genotypes. Saina (2005) reported ADG of $12.3 \mathrm{~g}$ for guinea fowls under an intensive system at the age of 16 weeks, which was higher as compared to the ADG recorded at 20 weeks in the present study. Similar to the present study, Mohammed and Dei (2017) recorded daily weight gains of $7.8 \mathrm{~g} / \mathrm{bird} /$ day for the first eight weeks of local GF keets brooded under an intensive management system. 
The variation in ADG from the current study might be due to the protein content of the feed, which was assumed to be a contributing factor to affect ADG as reported by Avornyo et al., (2013). The average daily gain of the GF keets declined as the growers fed crude protein content reduced to $18.5 \%$ in the commercial diet. In this regard, Seabo et al. (2011) noted that the feed intake and body weight gain of GF increased with increasing dietary protein. During the first eight weeks of the starter phase, GF had better ADG and final BW compared to chicken genotypes. In line with the current finding, Nahashon et al. (2006) reported a mean body weight of $787.1 \mathrm{~g}$ at eight weeks of age from a meat-type variety of GF in the USA. A lower live weight of $377.7 \mathrm{~g}$ at eight weeks of age in local GF raised under an intensive system was also reported in a study conducted in Bangladesh (Khairunnesa et al., 2016). The highest DM intake and ADG from PK could be a result of the past genetic improvement interventions made in this chicken breed.

For local chickens, Solomon Demeke (2003) observed a live weight of $1300 \mathrm{~g}$ under intensive production at 20 weeks of age, and Halima Moges et al. (2006) reported initial body weight, final body weight, ADG, and FCR of $27.2 \mathrm{~g}, 1191 \mathrm{~g}$, $7.6 \mathrm{~g}$, and 11.9 for Tilili local chickens under the indoor system, respectively. Wondmeneh Esatu (2015) also reported FBW of 964.2 and FCR of 12.4 for Horro chickens during 16 - 20 weeks under indoor system rearing. An FBW of 824.4 and $590.7 \mathrm{~g}$ at 20 weeks of age were reported for Savannah and Forest ecotypes of Benin local chicken ecotypes, respectively under an indoor system (Youssao et al., 2012). These authors also reported an ADG of $8.4 \mathrm{~g}$ and $5.8 \mathrm{~g}$ for Savannah and Forest ecotypes reared to 16 to 20 weeks of age. These results were lower when compared to the current findings for GF and local chicken genotypes. The higher result obtained in the current study could be an attribute of differences in the quality of feed offered to chickens, health care, and environmental conditions and the genetic difference between the ecotypes.

The FCR for the GF keets during the first eight weeks of age was 4.1, which was in the range of FCR value of $4-4.5$ reported for GF (Nobo et al., 2012). Seabo et al. (2011) reported an FCR values of 6.4 to 6.7 for GF keets fed on commercial poultry rations during the first six to 12 weeks of age, and was similar to the average FCR results (6.9) of the current study. Mwale et al. (2008) noted that decreasing FCR with the lower age could be due to increasing feed quantities needed for the fast growth. However, the result on DM intake of GF in the present study seems to be overestimated due to pronounced selective feeding and use of its beak for tearing with abrupt head movements, a form of behavior that leads to tremendous mash feed wastage from the feeders. The performances of GF during the first eight weeks of age indicated their growth potential on a better protein content diet indicating the opportunity to develop meat-type guinea fowls. Similarly, TL local chicken 
ecotypes possess the potential for the development of meat-type local chicken breed through selection as indicated by their relatively better growth. The PK showed greater performance than the GF and indigenous chicken genotypes in all parameters analyzed in the current study. The better DM intake and growth performances of PK might be attributed to genotypic differences. There was no statistical survivability difference among all genotypes. Confining the birds with the provision of sufficient and balanced feed, water, heat and light under an intensive management system significantly reduced keet and chicken mortality (Mohammed and Dei, 2017).

Significant differences were observed between chickens and domestic guinea fowls in terms of their carcass yield, gastrointestinal parts, and meat physicochemical properties. The dressing percentage (DP) of all of the genotypes tested was similar, suggesting that domestic GF can be adopted to complement chickens as a source of poultry meat in Ethiopia. Contrary to our findings, Musundire et al. (2018) reported that guinea fowls had heavier body weight and relative hot carcass and cold dressed weight than chickens from scavenging production system. The higher pre-slaughter live weight of chicken genotypes compared to GF genotypes has been associated with significantly heavier dressed, eviscerated, and primal meat cut weights. Besides the confinement of domestic GFs, which limited their performance, the lower results obtained for all of the parameters analyzed might be attributed to genotypic differences. In line with GF genotypes evaluated in the current study, the mean body weight of Sudanese GF from the Blue Nile population was reported to be $1263.3 \mathrm{~g}$ with the corresponding average dressed carcass weight of $934.1 \mathrm{~g}$ (Eltayeb et al., 2015). Similarly, the dressing percentage (DP) for poultry meat from the current study ranged from 72.2 to $74.8 \%$, which is in agreement with the average DP value of $73 \%$ (Muth et al., 2006). Moreover, the $75.4 \%$ DP of the GF reared under intensive management system (Ahaotu et al., 2019) and $72.8 \%$ for PK at 15 weeks of age (Melesse et al., 2013) were in line with the current findings.

A significantly higher share of breast muscles of GF as compared to chicken genotypes was in line with Swatland (1994), who reported extensive variation in poultry body proportions across breeds. Guinea fowls are fast runners, which could explain their lighter leg (thigh and drumstick) than chickens, which was in line with the report of Musundire et al. (2018). The lower weights observed for the prime cuts of breast, thigh, and drumsticks in guinea fowls might be due to the small skeletal frame of the GF compared to chicken genotypes, as reported by Musundire et al. (2018). Generally, the heavier carcass and carcass components obtained from the PK genotypes could be attributed to genotypic differences since PK is a dualpurpose line with a heavy frame (Van Marle-Köster et al., 2009). The greater gizzard, liver, and heart relative weights in chickens than in GF, might be due to the variation in species morphology and genetics. Guinea fowls and indigenous 
chickens of HR and TL accumulated less abdominal fat than PK in the study as they are characterized by having lean meat composition. It was stated that guinea fowl meat has a low-fat content of $4 \%$ as compared to chickens, beef (21\%), lamb (25\%), and pork (21\%), which makes it appealing to health-conscious consumers (Musundire et al., 2018). The heavier weight of the liver in PK and local chickens compared to GF can be related to the high abdominal fat content of the chicken species that makes animals prone to metabolic disorders such as fatty liver diseases and sudden death (Skrrivan et al., 2000). The higher abdominal fat contents of PK compared to GF and local chicken genotypes were consistent with the results obtained by Musundire et al. (2018).

The caecum is an important organ in the digestive system because it is responsible for cellulose digestion, fermentation and immune cell production (İlgün et al., 2018). Chicken caeca length was reported to range from 14.2 to $20.1 \mathrm{~cm}$ (Taşbaş, 1978). The GF caeca were longer than the chicken genotypes, which was in agreement with İlgün et al. (2018). The relatively long and heavy caeca observed for GF could be an attribute of scratching and ingesting grass used as litter material as observed during the entire experiment. Fibrous feed requires space for fermentation and cellulose digestion. The longer caeca might have the advantage to assist digestion of the fibrous feed materials. Since the experimental animals were all reared under the same housing and management conditions and compared at the same age, differences between breeds in the parameters measured indicate the genetic variations. Although the PK is top-performing among the birds compared, the local chicken genotypes and GF showed a promising result for carcass yield and characteristics, indicating the potential to develop local meat-type poultry species that are best adapted for future use through a selective breeding scheme.

The $\mathrm{pH}$ is one of the most important physicochemical characteristics in meat since it is related to water holding capacity and color (Bosque et al., 2020). The $\mathrm{pH}$ of broiler meat is the function of the amount of glycogen in the muscle before slaughter and the rate of glycogen conversion into lactic acid after slaughter (Mir et al., 2017). A high $\mathrm{pH}$ value shortens the meat shelf life since it creates a more favorable environment for bacteria (Sarica et al., 2019). The current study $\mathrm{pH}$ measurement results indicated that the initial $\mathrm{pH}\left(\mathrm{pH}_{15} \min \right)$ of breast and thigh meat was higher compared to the ultimate $\mathrm{pH}\left(\mathrm{pH}_{24 \mathrm{~h}}\right)$ for all of the genotypes in the current study, which is in line with the studies in Chinese indigenous chickens (Guan et al., 2013). The decline in postmortem $\mathrm{pH}$ can be related to the most important events in the conversion of muscle to meat due to its impact on meat texture, color, and water holding capacity and the rate of declining is dependent on the activity of glycolytic enzymes just after death and the initial glycogen reserves of the muscle (Devatkal et al., 2018). In line with the current findings, the pH of GF 
breast and thigh meat ranged between 6.1 and 6.5 (Kokoszynski et al., 2011). However, the breast and thigh-meat $\mathrm{pH}$ values from 18-weeks-old male GF reared under the indoor system had a higher value of 6.8 and 7.3 (Sarica et al., 2019) than in the present study. The $\mathrm{pH}$ values of breast and thigh meat of GF were higher than that of chicken genotypes (Laudadio et al., 2012). The $\mathrm{pH}$ value of the thigh meat in the current study was higher compared to the breast meat from all genotypes and mainly from GF, which is in agreement with the reports of Laudadio et al. (2012). In line with the current findings, the $\mathrm{pH}$ values from breast and thigh meat of Chinese indigenous chicken breeds were reported to range from 5.5 to 5.8 and 5.9 to 6.3 , respectively (Guan et al., 2013). Generally, the studies show that $\mathrm{pH}$ values for breast meat were lower compared to thigh meat. The $\mathrm{pH}$ of meat may be influenced by other internal factors such as muscle type, chicken strain, and external factors including feed, fasting, stress, electrical stimulation and chilling (Santos et al., 2005).

The $\mathrm{pH}$ of the meat seems to have a strong influence on the color of the meat. As a result, the meat from GF in the current study was darker than the meat from chicken genotypes. In this regard, it was noted that higher $\mathrm{pH}$ values resulting in darker meat color, while lower muscle $\mathrm{pH}$ values are associated with lighter meat (Wideman et al., 2016). For poultry fillets, the typical range of $\mathrm{pH}$ values $24 \mathrm{~h}$ after slaughter is between 5.6 and 6.2 (Bruckner et al., 2012), which can be considered normal. Hence, the ultimate $\mathrm{pH}$ results of all genotype breast in the present study are in line with the above range indicating the meat from all poultry genotypes fall within the normal range.

Besides the meat $\mathrm{pH}$ value, meat color is highly correlated to the amount of haemcontaining compounds such as myoglobin, haemoglobin, and cytochrome-c (Wideman et al., 2016). Meat color is one of the first traits noticed by consumers and thus an indicator of meat quality (Guan et al., 2013). Therefore, the characteristic differences in meat color of the current study between GF and chicken genotypes may influence consumer preference when they are used to make the same dish (Jayasena et al., 2013). Qiao et al. (2001) determined the border values for color of chicken breast muscle: lighter than normal ( $\left.\mathrm{L}^{*}>53\right)$, normal $\left(48<\mathrm{L}^{*}<\right.$ $53)$ and darker than normal $\left(\mathrm{L}^{*}<48\right)$. According to this border value, the lightness $\left(\mathrm{L}^{*}\right)$ color values in the present study for the fresh and cold raw breast meat without skin from chicken genotypes fall under the normal range, while that of GF breast meat tends to be darker than normal. Chicken breast meat generally appears to have a pink color, which is considered a desirable characteristic by the consumers and has a normal color (Choo et al., 2014).

The lightness color $\left(\mathrm{L}^{*}\right)$ for thigh meat from chicken genotypes from the current study is in line with the values ranged from $41.78-42.6$ for fowl thigh meat 
(Tufarelli and Laudadio, 2015; Kokoszynski et al., 2011; Laudadio et al., 2012). The L* value of chicken breast and thigh meat is higher than the GF breast and thigh meat, which can be related to lower $\mathrm{pH}$ values of chicken breast and thigh meat (Hasan et al., 2019), where the $\mathrm{L}^{*}$ value of broiler breast meat was higher than cockerel breast meat with the lower $\mathrm{pH}$ values of broiler breast meat. The thigh meat $\mathrm{L}^{*}$ color in GF genotype was in line with the previous relationship of $\mathrm{pH}$ value and $\mathrm{L}^{*}$ values. It is well documented that the darker color of leg/thigh meat is due to the larger amount of myoglobin and haem pigments, as well as relatively a higher $\mathrm{pH}$ when compared to breast meat (Wideman et al., 2016). It was noted that the red fibers are high in myoglobin as compared to white fibers and hence contributed to the thigh meat color to have a lower lightness value from the current study (Barbut, 2001). This was because the leg and thigh meat have a higher proportion of red muscle fibers, while the breast meat is almost entirely composed of white fibers.

The redness $\left(\mathrm{a}^{*}\right)$ color in GF breast meat after cold storage for $24 \mathrm{~h}$ was higher compared to chicken genotypes, which is consistent with the reports of Bosque et al. (2020). The redness ( $\left.\mathrm{a}^{*}\right)$ values of breast and thigh meat of GF from the current study was higher and lower than the values reported by Sarica et al. (2019) and Kokoszynski et al. (2011), respectively but similar to that of Laudadio et al., (2012). In agreement with the present finding, a higher value of redness in GF meat in comparison to broilers chickens was reported by López-Pedrouso et al. (2019). Although the genetic differences might have contributed to the variation in breast and thigh meat color, the tendency for GF meat to be darker or redder under an intensive production system might be due to slower growth and higher physical activity in the experimental pens.

There was no difference among genotypes in the yellowness $\left(b^{*}\right)$ color of breast meat, but chicken showed a higher yellowness color for thigh muscle cut compared to the GF. However, the values in yellowness color $\left(b^{*}\right)$ of the current study is in line with the values ranged from 8.2 to 13.8 reported for the breast meat of four different Chinese indigenous chicken genotypes (Guan et al., 2013). Contrary to the current yellowness $\left(b^{*}\right)$ color result, lower values of 5.1 and 2.0 for breast and thigh meat of GF, respectively (Sarica et al., 2019), and higher values (17.4 - 19 for breast and 17.2 - 18.9 for thigh) for Korean native chickens (Jayasena et al., 2013) were reported. The higher yellowness color content of the thigh muscle from HR and PK may be related to the higher intramuscular fat content of the meat cut from this muscle portion (Fanatico et al., 2005). 


\section{CONCLUSION}

The DM intake, ADG, and the final BW were confirmed to vary with bird genotypes, whereby PK had higher values. Similarly, slaughter, dressed, and eviscerated weights of the carcass varied with chicken genotypes, i.e., high for PK. Patterns were the same for the main meat cuts and the breast weight. Higher abdominal fat content from PK might be associated with higher liver weight. Higher caeca length and weight observed on GF might be related to the feeding habit of the bird. Adaptation to scavenging also appeared to have a role, where GF birds were found more stressed in confined conditions. The $\mathrm{pH}$ values of meat cuts followed a similar pattern in all genotypes, i.e., high for initial $\mathrm{pH}$ and less for ultimate $\mathrm{pH}$. Meat color varied with part of the meat cuts, i.e, breast (normal) for chicken and thigh (dark), whereas both meat cuts of GF inclined to be dark. From the result of the current study, it could be concluded that the higher performance of PK genotypes for all parameters investigated is expected since the breed was a welldeveloped dual-purpose breed of South Africa. The relative performance recorded by HR and TL chicken genotypes showed the potential for implementing future selection and breeding schemes to use as alternate locally adapted meat-type poultry breeds.

\section{ACKNOWLEDGEMENTS}

The authors express their gratitude to the International Livestock Research Institute (ILRI)-African Chicken Genetic Gain (ACGG) Project for granting the research fund and the Ethiopian Institute of Agricultural Research (EIAR) for facilitation of the budget. We are also thankful to the Amhara Agricultural Research Institute (ARARI) for granting the correspondent author for granting the study leave and covering part of the research cost and the Andassa Livestock Research Center (ALRC) for allowing the use of research facilities.

\section{Conflict of interest}

The authors declare no conflicts of interest regarding the publication of this paper.

\section{REFERENCES}

Ahaotu, E.O, Nwafor, C., Onyebuchukwu, P.A and Okpara, O. (2019). Carcass, organ weights and egg quality characteristics of guinea fowl layers fed varying levels of butterfly pea leaf (Centrosema Pubescens) meal. Sustainability, Agri. Food and Environmental Research 7(1): 37-51.

AMSA (American Meat Science Association). (2012). Meat Color Measurement Guidelines. AMSA, Champaign, IL. 
Avornyo, F.K., Salifu, S., Moomen, A and Agbolosu, A.A. (2013). Effect of dietary protein on the performance of local guinea keets in the Northern Region of Ghana. Greener Journal of Agricultural Sciences 3(7): 585-591.

Barbut, S. (2001). Basic anatomy and muscle biology. Poultry products processing: An industry guide. CRC Press Washington D.C. pp. 31-60.

Bosque, C.E., Altmann, B.A, Ciulu, M., Halle, I., Jansen, S., Nolte, T., Weigend, S and Mörlein, D. (2020). Meat quality parameters and sensory properties of one high-performing and two local chicken breeds fed with Vicia faba. Foods 9: 1052. doi:10.3390/foods9081052

Bruckner, S., Albrecht, A., Petersen, B and Kreyenschmidt, J. (2012). Characterization and comparison of spoilage processes in fresh pork and poultry. Journal of Food Quality 35(5): 372-382.

CAB International (1987). The technical center for agricultural and rural cooperation. Manual of poultry production in the tropics. Cambrian News Ltd, Aberytwyth, UK.

Choo, Y.K., Kwon, H.J., Oh, S.T., Um, J.S., Kim, B.G., Kang, C.W., Lee, S.K and An, B.K. (2014). Comparison of growth performance, carcass characteristics and meat quality of Korean local chickens and silky fowl. Asian Australasian Journal of Animal Sciences 27(3): 398-405.

Copland, J.W and Alders, R.G. (2005). The Australian village poultry development program in Asia and Africa. World's Poultry Science Journal 61: 31-38.

Devatkal, S.K, Vishnuraj, M.R., Kulkarni, V.V and Kotaiah, T. (2018). Carcass and meat quality characterization of indigenous and improved variety of chicken genotypes. Poultry Science 97: 2947-2956. doi:10.5897/AJB11.1747.

Eltayeb, N.M., Yousif, I.A., Elamin, K.M and Abdel Hamid, M.M. (2015). Determination of growth performance and carcass characteristics of Sudanese guinea fowl (Numida meleagris) in different location. Journal of Animal Science Advances 5(11): 1473-1479. doi: 10.5455/jasa.20151118111140.

Fanatico, A.C., Cavitt, L.C., Pillai, P.B., Emmert, J.L and Owens, C.M. (2005). Evaluation of slowergrowing broiler genotypes grown with and without outdoor access: meat quality. Poultry Science 84(11): 1785-1790.

Guan, R., Lyu, F., Chen, X., Ma, J., Jiang, H and Xiao, C. (2013). Meat quality traits of four Chinese indigenous chicken breeds and one commercial broiler stock. Journal of Zhejiang University-Science B (Biomedicine and Biotechnology) 14(10): 896-902. doi:10.1631/jzus.B1300163.

Halima Hassen (2007). Phenotypic and genetic characterization of indigenous chicken populations in Northwest Ethiopia. PhD Thesis. Faculty of Natural and Agricultural Sciences, Department of Animal, Wildlife and Grassland Sciences, University of the Free State, Bloemfontein, South Africa.

Halima Hassen, Neser, F.W.C., de Kock, A and Van Marle-Köster, E. (2006). Growth performance of indigenous chickens under intensive management conditions in Northwest Ethiopia. South African Journal of Animal Science 36(5): 71-73.

Hasan, M.N., Rabbani, M.A.G., Yeasmin, T., Hasan, M and Rassid, H.O. (2019). A comparative study of carcass characteristics and meat quality traits of breast muscle between broiler and cockerel chicken. International Journal of Poultry Science 18: 144-150.

İlgün, R., Gür, F.M, Bölükbaş, F and Yavuz, O. (2018). Macro anatomical and histological study of caecum of the guinea fowl (Numida meleagris) using light and scanning electron microscopy. Indian Journal of Animal Research 52(6): 858-863. doi: 10.18805/ijar.B-72.

Jayasena, D.D., Jung, S., Kim, H.J., Bae, Y.S., Yong, H.I., Lee, J.H., Kim, J.G and Jo, C. (2013). Comparison of quality traits of meat from Korean native chickens and broilers used in two different traditional Korean cuisines. Asian Australian Journal of Animal Science 26: 1038-1046.

Kekeocha, C.C. (1985). Introduction to poultry keeping. pp. 1-15. In: Poultry Production Hand Book, Pfizer Corporation, Nairobi.

Khairunnesa, M., Das, S and Khatun, A. (2016). Hatching and growth performances of guinea fowl under an intensive management system. Progressive Agriculture 27(1): 70-77. doi.org/10.3329/pa.v27i1.27544. 
Kokoszynski, D., Bernacki, Z., Korytkowska, H., Wilkanowska, A and Piotrowska, K. (2011). Effect of age and sex on slaughter value of guinea fowl (Numida meleagris). Journal of Central European Agriculture 12: 255-266.

Kubena, L., Wchen, F.J and Reece, F.N. (1974). Factors influencing the quality of abdominal fat in broilers. III. Feed and dietary levels. Journal of Poultry Science 53: 974-978.

Laudadio, V., Nahashon, S.N and Tufarelli, V. (2012). Growth performance and carcass characteristics of guinea fowl broilers fed micronized-dehulled pea (Pisum sativum L.) as a substitute for soybean meal. Poultry Science 91: 2988-2996.

López-Pedrouso, M, Cantalapiedra, J., Paulo, E. S. Munekata, Francisco, J. B, Lorenzo, J.M and Franco, D. (2019). Carcass characteristics, meat quality and nutritional profile of pheasant, quail and guinea fowl (eds.), More than beef, pork and chicken. The production, processing, and quality traits of other sources of meat for human diet, https://doi.org/10.1007/978-3-030-05484-7-10.

Melesse, A., Dotamo, E., Banerjee, S., Berihun, K and Beyan, M. (2013). Studies on carcass traits, nutrient retention and utilization of Koekoeck chickens fed diets containing different protein levels with Iso-Caloric ration. Journal of Animal Science Advances 3(10): 532-543.

Mir, N.A., Rafiq, A., Kumar, F., Singh, V and Shukl, V. (2017). Determinants of broiler chicken meat quality and factors affecting them: a review. Journal of food science technology 54(10): 2997-3009.

Mohammed, A and Dei, H.K. (2017). Comparative performance of guinea keets managed under two brooding systems in the Tolon District of Northern Region of Ghana. International Journal of Development 4(1): 42-45.

Musundire, M.T., Halimani, T.E and Michael-Chimonyo, M. (2018). Effect of age and sex on carcass characteristics and internal organ weights of scavenging chickens and helmeted guinea fowls. Journal of applied animal research 46(1): 860-867. doi: 10.1080/09712119.2017.1411266.

Muth, M.K., Beach, R.H., Karns, S.A., Taylor, J.L and Viator, C.L. (2006). Poultry slaughter and processing sector facility-level model. Research Triangle Institute. Project Report (NC, USA).

Mwale, M., Mupangwa, J.F and Mapiye, C. (2008). Growth performance of guinea fowl keets fed graded levels of baobab seed cake diets. International Journal of Poultry Science 7: 429-432.

Nahashon, S.N., Aggrey, S.E., Adefope, N.A., Amenyenu, A and Wright, D. (2006). Growth characteristics of pearl gray guinea fowl as predicted by the Richards, Gompertz, and logistic models. Poultry Science 85: 359-363.

Nigussie Dana (2011). Breeding programs for indigenous chicken in Ethiopia analysis of diversity in production systems and chicken populations. $\mathrm{PhD}$ Thesis, Wageningen University, The Netherlands.

Nobo, G., Moreki J.C and Nsoso, S.J. (2012). Feed intake, body weight, average daily gain, feed conversion ratio and carcass characteristics of helmeted guineafowl fed varying levels of phane meal (Imbrasia belina) as replacement of fishmeal under intensive system. International Journal of Poultry Science 11(6): 378-384.

Premavalli, K. (2013). Influence of strain, age and system of management on the productive and reproductive performance of guinea fowl. PhD Thesis, Tamil Nadu Veterinary and Animal Sciences University, Chennai - 600 007, India.

Qiao, M., Fletcher, D.L., Smith, D.P and Northcutt, J.K. (2001). The effect of broiler breast meat color on $\mathrm{pH}$, moisture, water-holding capacity, and emulsification capacity. Poultry Science 80(5): 676-680. doi: $10.1093 / \mathrm{ps} / 80.5 .676$.

Saina, H. (2005). Guineafowl (Numida meleagris) production under smallholder farmer management in Guruve District, Zimbabwe, MSc Thesis, University of Zimbabwe, Harare, Zimbabwe.

Santos, A.L., N.K. Sakomura, E.R. Freitas, C.M.L.S. Fortes, E.N.V.M. Carrilho and Fernandes, J.B.K. (2005). Growth, performance, carcass yield and meat quality of three broiler chicken strains. Revista Brasileira de Zootecnica 34: 1589-1598.

Sarica, M., Boz, M.A., Yamak, U.S and Ucar, A. (2019). Effect of the production system and slaughter age on some production traits of guinea fowl: Meat quality and digestive traits. South African Journal of Animal Science 49(1): 194-199.

SAS (Statistical Software System) (2009). SAS user's guide, statistics. SAS Institute, Inc., Cary, NC. USA. 
Seabo, D., Moreki, J.C., Bagwasi, N and Nthoiwa, G.P. (2011). Performance of guinea fowl (Numida meleagris) fed varying protein levels. Online Journal of Animal Feed Research 1(6): 255-258.

Shapiro, B.I., Getachew, G., Solomon, D., Asfaw, N., Kidus, N., Gezahegn, A and Henok, M. (2015). Ethiopia livestock master plan. ILRI Project Report. Nairobi, Kenya: International Livestock Research Institute (ILRI).

Skřivan, M., Skřivanová, V., Marounek, M., Tůmová, E and Wolf, J. (2000). Influence of dietary fat source and copper supplementation on broiler performance fatty acid profile of meat and depot fat, and on cholesterol content in meat. British Poultry Science 41: 608-614.

Solomon Demeke (2003). Growth performance and survival of local and White Leghorn chickens under scavenging and intensive systems of management in Ethiopia. Research for Rural Development 15 (11). Article $\# 83$

Swatland, H.J. (1994). The conversion of muscle to meat. In: Swatland, H.J. (ed.). Structure and development of meat animals and poultry. Lancaster: Technomic Publishing.

Tadelle, D., Kijora, C and Peters, K.J. (2003). Indigenous Chicken Ecotypes in Ethiopia: Growth and Feed Utilization Potentials. International Journal of Poultry Science 2(2): 144-152.

Taşbaş, M. (1978). Comparative macro-anatomic and sub-gros studies on the digestive systems of chicken-cock (Gallus domesticus) and turkey (Meleagris gallopavo) of domestic wingers. Part:2Between esophagus and cloaca. Veterinary Journal of Ankara University 25(3): 500-516.

Tufarelli, V and Laudadio, V. (2015). Feeding of dehulled-micronized faba bean (Vicia faba var. minor) as substitute for soybean meal in guinea fowl broilers: Effect on productive performance and meat quality. Asian-Australian Journal of Animal Science 28(10): 1471-1478.

Van Marle-Köster, E., Hefer, C.A., Nel, L.H and Groenen, M.A.M. (2009). Genetic diversity and population structure of locally adapted South African chicken lines: Implications for conservation. South African Journal of Animal Science 38(4): 271-281.

Wideman, N., O'Bryan, C.A and Crandall, P.G. (2016). Factors affecting poultry meat color and consumer preferences: A review. World's Poultry Science Journal 72: 353-366. doi:10.1017/S0043933916000015.

Wondmeneh Esatu Woldegiorgis (2015). Genetic Improvement in Indigenous Chicken of Ethiopia, PhD Thesis, Wageningen University, NL with references, with summaries in English and Dutch ISBN 978-94-6257-316-1.

Wondmeneh, E., Dawud, I and Adey, M. (2011). Comparative evaluation of fertility and hatchability of Horro, Fayoumi, Lohmann Silver and Pochefstroom Koekoek breeds of chicken. Asian Journal of Poultry Science 5(3): 124-129. doi:10.3923/ajpsaj.2011.124.129.

World Population Review (2020). http://worldpopulationreview.com/countries/ethiopiapopulation/Internate.

Youssao, I.A.K., Alkoiret, I.T., Dahouda, M., Assogba, M.N., Idrissou, N-D., Kayang, B.B., YapiGnaoré, V., Assogba, H.M., Houinsou, A.S., Ahounou, S.G., Tougan, U.P., Rognon, X and TixierBoichard, M. (2012). Comparison of growth performance, carcass characteristics and meat quality of Benin indigenous chickens and Label Rouge (T55 $\times$ SA51). African Journal of Biotechnology 11(89): $15569-15579$. 